\title{
Cretaceous Stratigraphy, Paleoenvironment and Terrestrial Biota in Shandong Province
}

\author{
Hongwei Kuang ${ }^{*}$, Yongqing Liu' ${ }^{1}$, Kemin $\mathrm{Xu}^{2}$, Zhenguo Ning ${ }^{2}$, Nan Peng ${ }^{1}$ \\ ${ }^{1}$ Institute of Geology, Chinese Academy of Geological Sciences, Beijing, China \\ ${ }^{2}$ Shandong Institute of Geological Survey, Jinan, China \\ Email: *kuanghw@126.com
}

How to cite this paper: Kuang, H.W., Liu, Y.Q., Xu, K.M., Ning, Z.G. and Peng, N. (2019) Cretaceous Stratigraphy, Paleoenvironment and Terrestrial Biota in Shandong Province. Open Journal of Geology, 9, 650-653.

https://doi.org/10.4236/ojg.2019.910065

Received: August 16, 2019

Accepted: September 21, 2019

Published: September 24, 2019

Copyright ( 2019 by author(s) and Scientific Research Publishing Inc. This work is licensed under the Creative Commons Attribution International License (CC BY 4.0).

http://creativecommons.org/licenses/by/4.0/

\begin{abstract}
The terrestrial upper Jurassic-Cretaceous (upper and lower)-Cenozoic stratigraphic succession developed continuously in Shandong province. There are intact and continuous terrestrial paleoecosystems dominated by dinosaurs, including five vertebrate fauna (bone fossil assemblages) beds from the bottom to top in the Cretaceous successions of Shandong Province. There are multiple vertebrate footprints (group) bearing beds in the transition period between Jurassic-Cretaceous and Early Cretaceous, and multiple large-scale dinosaur burial bone beds in Late Cretaceous. In recent years, it has also been found that extraterrestrial impact geological event may occur in the $\mathrm{K} / \mathrm{Pg}$ transition over a hundred meters (siliceous pellet and gamma element anomalies, etc.). Shandong has a well-developed terrestrial Cretaceous succession with perfect information on paleoenvironment and paleoecology, which is an ideal area to explore the co-evolutionary relationship between terrestrial biota and paleoenvironment.
\end{abstract}

\section{Keywords}

Cretaceous, Paleoenvironment, Terrestrial Biota, Shandong Province

\section{Shandong Province Developed the Most Systematic and Complete Continental Cretaceous Stratigraphic Succession}

In recent 10 years, on the basis of predecessors' researchers, our team not only systematically set and updated the Cretaceous succession of Shandong Province, but also further divided it into the $\mathrm{J}_{3}-\mathrm{K}_{1}^{1}$ (Mengyin Group between transitional Jurassic-Cretaceous), $\mathrm{K}_{1}^{2}$ (Lower Cretaceous Laiyang Group), K13 (Lower Cretaceous Qingshan Group/Dasheng Group), $\mathrm{K}_{2}^{1}$ (the lower part of Hongtuya 
Formation of the Upper Cretaceous Wangshi Group) and $\mathrm{K}_{2}^{2}$ (the upper part of Hongtuya Formation of the Upper Cretaceous Wangshi Group). Especially combined with a large number of measured chronological data, we established a comprehensive Cretaceous litho-chronostratigraphic framework with high-precision, and preliminarily summarized the paleogeographic evolution model of Cretaceous sedimentary basin [1] [2] [3] [4].

\section{It Contains Cretaceous Paleogeographic Evolution Information}

The Cretaceous basin is only developed in western Shandong, which is a fluvial-lacustrine environment with no strong volcanic activities in $\mathrm{J} / \mathrm{K}_{1}^{1}$ transitional period ( 145 - $132 \mathrm{Ma})$. The basin extends to eastern Shandong during K12 $(\sim 132-125 \mathrm{Ma})$ [3] [4], which was dominated by extensive lacustrine environment. Magma intrusion and volcanic eruption (Qingshan Group) occurred briefly but strongly, and intermittent alluvial-fluvial-lacustrine facies environment existed in the early K13 ( 125 - $120 \mathrm{Ma})$. Rift basin was mainly developed along the Yishu Fault zone, dominated by wide-shallow lake environment in the late K13 period ( 120 - $100 \mathrm{Ma})$ [2]. An extremely hot and arid climate prevailed during the K21 - K22 deposited. Braided rivers dominated in the northern Jiaolai Basin and western Shandong while alluvial fan-fluvial and lacustrine environments co-existed in the central and southern part of Jiaolai Basin [5].

\section{It Develops Well-Preserved Terrestrial Ecosystem}

Cretaceous in Shandong Province not only outcrops continuously, but also develops 5 sets of vertebrate fossil assemblages dominated by dinosaurs from Early to Late Cretaceous. They are:

1) The Euhelopus zdanskyi, the largest sauropod ever described in China developed in J/K11 in western Shandong Provinces. 2) Psittacosaurus of the Linjiazhuang Formation in Jiaolai Basin in K13. 3) Ornithopoda duck-billed dinosaur Shantungosaurus assemblage in K21, including Shantungosaurus, Zhuchengosaurus maximus Zhao et al. and Giant cathaysian, Accompanying ceratosaurs, such as Sinoceratops zhuchengensis gen. et sp. nov, theropod Zhucheng tyrannosaurus rex, Zhuchengtyrannus magnus, as well as a few ankylosaur, coelurosauria scattered bones. 4) Taniussinensis assemblage, accompanied by a number of other dinosaur bone fossils, and a large number of dinosaur egg fossils in K22 in Jiaolai basin. 5) The ornithopoda assemblage represented by Tsintaosaurusspinorhinusis also symbiosis with fossil dinosaur eggs in K22 in Jiaolai Basin [5].

The assemblage and buried situation of dinosaur fauna not only reveal the differences of living and buried environment among different dinosaur faunas, but also directly relate to the evolution of Cretaceous paleogeography and paleoclimate. At the same time, the Lower Cretaceous in Shandong Province also has abundant and diverse vertebrate relics dominated by dinosaurs and birds 
with a very high distribution density, which reflects the habitats of diverse vertebrate fauna and their systematic evolution characteristics [2]. The dinosaur footprints of theropods, sauropods, ornithopods and other different species [2], pterosaur footprints were developed in the Early Cretaceous and J/K transition period.

\section{K/Pg Boundary Recorded Extraterrestrial Impact Event}

Several vitreous spherulite layers more than 100 meters thick found on top of K2 [6] and abnormal combination of Ir and Pt elements at K/Pg transition site [7] may indicate the occurrence of extraterrestrial impact events.

Therefore, successions in Shandong Province not only developed complete terrestrial cretaceous stratigraphic sequence, but also bored abundant and diverse information of paleoenvironment (sedimentary basin, paleogeography, paleoclimate and geological events, etc.), evolution and replacement. Especially, it also preserved continuous and perfect ecological system information (flora and fauna and fossil assemblage), and together constituted a complete Cretaceous record of environment evolution, different biome initiation, radiation, replacement or dying or even extinction.

\section{Acknowledgements}

This research is co-supported by the National Key Research and Development Program of China (No. 2018YFC0604201), NFSC (No. 41272021, 41672111 and 41372109), the Central Project of NFSC (No. 41688103) and Geological Survey of China (DD20190005). This is a contribution to UNESCO/IUGS/IGCP 679 project.

\section{Conflicts of Interest}

The authors declare no conflicts of interest regarding the publication of this paper.

\section{References}

[1] Liu, Y.Q., Kuang, H.W., Ji, S.A., Lv, J.C., Liu, Y.X., Jiang, X.J., et al. (2009) The Biotic and Environmental Response to the Geological Event on the Earth during the Late Mesozoic. Earth Science Frontiers, 16, 37-47.

[2] Kuang, H.W., Liu, Y.Q., Wu, Q.Z., Cheng, G.S., Xu, K.M., Liu, H., et al. (2013) Dinosaur Track Sites and Palaeogeography of the Late Early Cretaceous in Shuhe Rifting Zone of Shandong Province. Journal of Palaeogeography, 15, 435-453.

[3] Peng, N., Liu, Y.Q., Kuang, H.W., Xu. H., Zhang, P., Chen, J., et al. (2015) Provenance of Early Cretaceous Laiyang Group in Jiaolai Basin and Its Significance. Geology in China, 42, 1793-1810.

[4] Zhang, P., Kuang, H., Liu, Y., Meng, Z., Peng, N. and Xu, H. (2018) Sedimentary Characteristics and Provenance of the Basal Conglomerate of the Late Jurassic-Early Cretaceous Jiaolai Basin, Eastern China and Their Implications for the Uplift of the Sulu Orogenic Belt. International Geology Review, 61, 521-538. 
https://doi.org/10.1080/00206814.2018.1437786

[5] Kuang, H.W., Liu, Y.Q., Dong, C., Peng, N., Wang, B.H., Zhang, P., et al. (2014) Research on Taphonomy of Late Cretaceous Dinosaurs in Zhucheng, Eastern Shandong, China. Acta Geologica Sinica, 88, 1353-1371.

[6] Xu, K.M., Kuang, H.W., Qin, J., Wang, Y.P., Peng, N., Ning, Z.G., et al. (2017) New Discovery of Terrestrial K-Pg Boundary from Jiaolai Basin of Shandong Province. Geology in China, 44, 94-195.

[7] Ding, C. (2016) The Ostracod Biostratigraphy and the K/Pg Boundary Discussion an Lk1 Core, Jiaolai Basin. China University of Geosciences, Beijing. 